\title{
駒ケ岳火砕流堆積地における森林造成地の推移と植生回復過程
}

\author{
櫻井彰人*・新谷 融*・柳井清治**
}

\section{Natural and Managed Forest Recovery after a Volcanic Eruption}

\author{
SAKURAI, Akihito*, Araya, Tohru*, YAnaI, Seiji** \\ 要旨
}

1929年に大規模な火山噴火を起こした北海道西南部駒ケ岳山麓の火砕流堆積地におい て, 噴火後60年間の植生回復の過程と, 1963年から始まった木本導入施工地における生長 成績から, 人為の植栽が森林復元に及ぼす意義に関して検討を行った。調査の結果, 再生 林は先駆性広葉樹であるヤナギ類, カンバ類, ヤマナラシおよびドロノキの $3 \mathrm{~m}$ 以下の矮 性林と, 移入樹種であるカラマツの稚樹群から構成されていた。年輪解析から, 噴火後侵 入してきた広葉樹類に変わってカラマツが優勢を占めつつあるが, 森林化するまでにはま だ長い時間を要することがわかった。 次に, 植栽工施工地でクロマツ, ハンノキ, シラカ ンバおよびカラマツの主要導入樹種について成績を調べたところ, カラマツは最も生長が よく最大樹高で $10 \mathrm{~m}$ に達し, ハンノキ, クロマツもこれに次ぐ成績であるが, シラカンバ は極めて成績が悪かった。クロマツ, ハンノキ, シラカンバは風倒, 幹折れなどの損傷が 著しい。また，林内には周辺からミズナラ等の侵入がみられた。土壌化に関しては, 主に ケヤマハンノキにおいて, 経過年数の長いものほど, 土層厚, 全炭素・窒素ともに高い值 を示していた。以上のことから再生林と比較して, 木本を導入することにより早期に森林 を造成するという目標は達せられたと考えられた。今後は, 衰退しつつある導入林をより 安定した広葉樹林へと導くことが大きな課題である。

\section{1. はじめに}

北海道内には活火山が数多く分布し, 1977年の有珠山， 1989年の十勝岳など頻繁に噴火して山麓周辺に大きな被 害をもたらしている。こうした火山活動により形成され た広大な裸地から地表面の侵食が増大するため, この裸 地にいかに速く植生を回復させ, 森林に復元するかが治 山砂防技術の大きな課題となっている

一般的に, 火山噴出物が厚く堆積した場所では, 水分 や栄養条件が極めて劣悪であるため, 木本の植栽には多 くの困難を伴い, 実際の代表的な森林造成例は昭和新

キーワード : 活火山, 火砕流堆積地, 植生回復, 木本導入

Key words : Active volcano, Pyroclastic flow deposits, Vegetation recovery process, Tree planting

* 北海道大学農学部

Dep. of Forest Science, Fac. of Agri., Hokkaido Univ.

** 北海道立林業試験場

Hokkaido Forest Res. Inst.

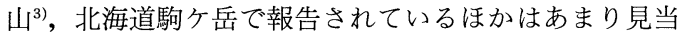
たらない。また最近では, 草本により短期間に地表を被 覆する試みが一般的に行われるようになってきたが, 残 存した導入草本が郷土樹種の侵入を防げ, 森林への移行 がスムーズに行われないという指摘もある ${ }^{4,5,10)}$ 。また, 火 山性荒廃地での森林造成を行うためには, 侵食の防止と ともに早期に木本の導入を図ることが重要である ${ }^{9)}$ 。そ して木本の導入にともなう様々な問題を解決するために は, 荒廃地から森林までの回復プロセスを明らかにする とともに, 実際の施工地での工法の評価を行うことが有 効である。

1929年に噴火した北海道南西部駒ケ岳では過去30年間 にわたり木本導入が行われ，荒廃地はすでに森林により 被覆されてきている。同時にここでは自然侵入プロセス も観察でき, 火山性荒廃地での植生遷移を知る上での貴 重な実験地となっている ${ }^{12,17)}$ 。筆者らは駒ケ岳における 噴火後 60 年を経た植生実態と, 30 年前から実施されてい 
る植栽地の生長成績を比較検討し, 活火山山麓における 森林造成の意義について検討した。

\section{2. 調査地概要}

北海道駒ケ岳 $(1133 \mathrm{~m})$ は, 北海道南西部渡島半島に 位置する活火山であり, 過去から活発に噴火活動を繰り 返し, 1640 年の大噴火では大規模な山体崩壊が発生した。 さらに，1929年の噴火では，破局的噴火が約14時間継続 し，降下軽石と同時に火砕流が発生した。降下軽石堆積 物は東から南東山麓に分布しており, 火砕流堆積物はほ ぼすべての方向に流下した。また, 噴火終焉後の翌日に は降雨のため, 二次的な泥流が流下した ${ }^{6,11)}$ 。この噴火に より, 2400 ha におよぶ森林と耕地が一瞬にして裸地と なった。現在, 火砕流堆積地はカラマッ, ヤマナラシ, ドロノキ, カンバ類を主とする矮性林となっている。ま た同堆積地の周囲には, カシワ，ミズナラ，ハリギリ等 が優先する広葉樹林がみられる。
調査地は，駒ケ岳北西山麓の森町尾白内地区における 1929年火砕流堆積地である。同火砕流は長さ $5 \mathrm{~km}$, 幅 $1.5 \mathrm{~km}$ の範囲に堆積しており, その厚さは $3 \sim 25 \mathrm{~m} に$ のぼり ${ }^{6}$, 既存の植生は完全に焼失した ${ }^{13,15)}$ (図 1 )。周辺 の潮風防止と表土飛散防止のために，同堆積物上の標高 60〜360 m の緩斜面において，噴火後34年経過した1963 年から民有林治山が開始された。植栽は各年 10 ha 程度 ずつ行われ，現在ではその面積が約 200 ha に及んでいる (表 1 )。また, 植栽本数は植栽年度によって異なるが, $4 \sim 10$ 千本/haである。植栽樹種はクロマツ (Pinus thunbergii), ヨーロッパアカマツ (P. sylvestris), ケヤ マハンノキ (Alnus hirsuta), シラカンバ (Betula platy phylla var. japonica), カラマツ (Larix leptolepis), グ イマツ (L. gmelini) およびその育種選抜樹種 F1を主と し，その他アカマツ (Pinus densiflora), バンクスマツ (P. banksiana), ストローブマツ(P. strobus), トドマツ (Abies sachalinensis), ドロノキ (Populus maximowic-

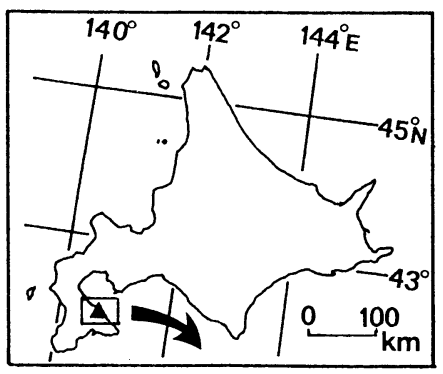

図 1 調査地位置図

Fig. 1 Location of the studied sites

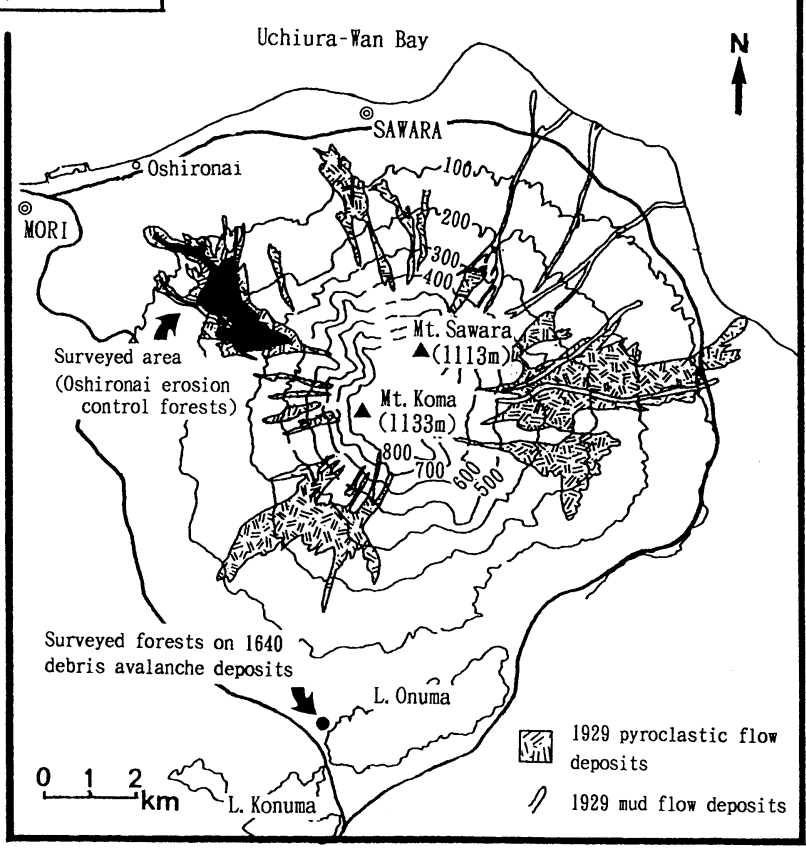


表 1 樹種ごとの植栽期間（1992年度現在）

Table 1 Period of planting and examined plots

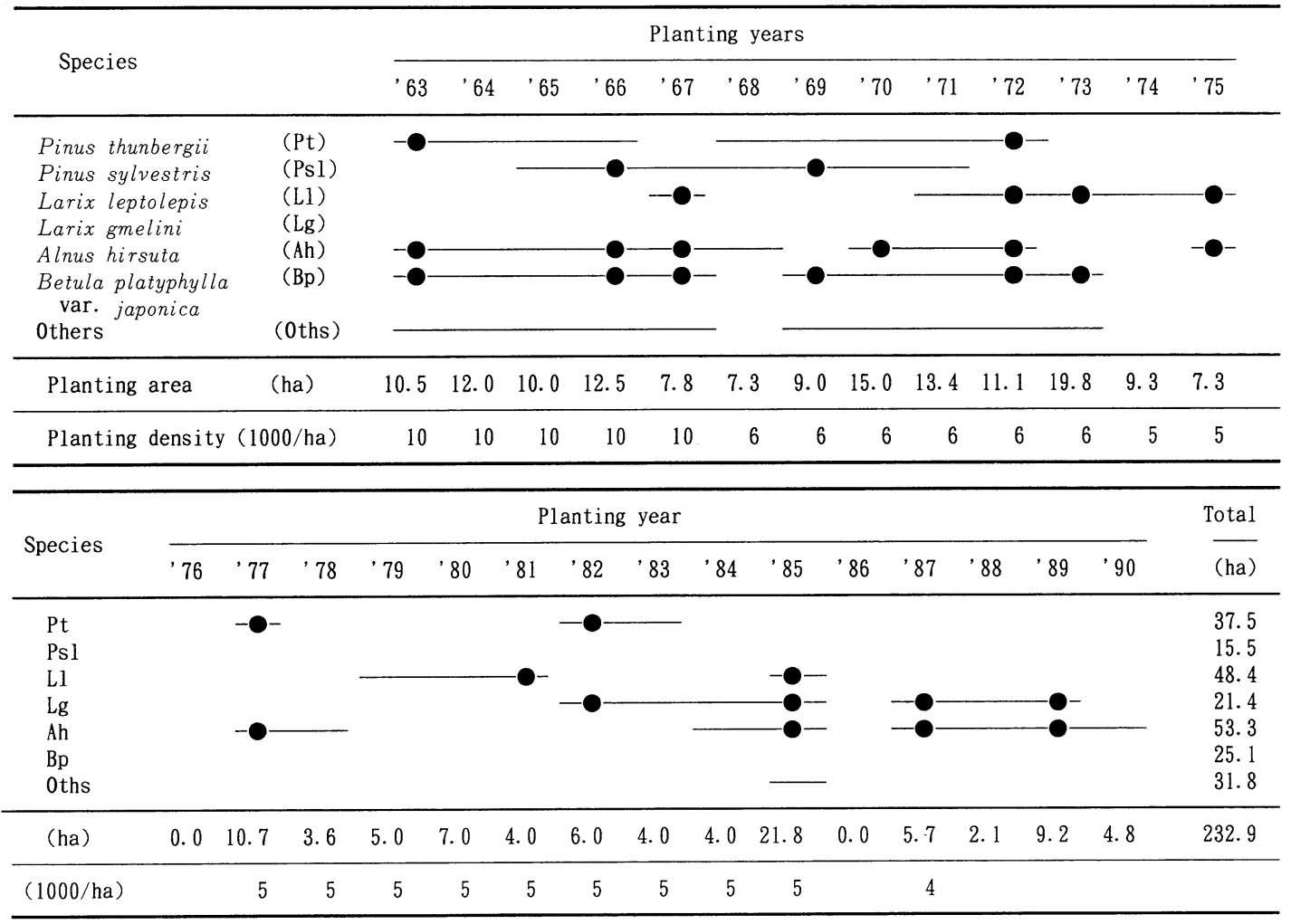

注） ラインは植栽期間を表し, ○は調査対象地を示す.

Note: Horizontal lines and dots $(\bullet)$ represent period of planting and examined plots.

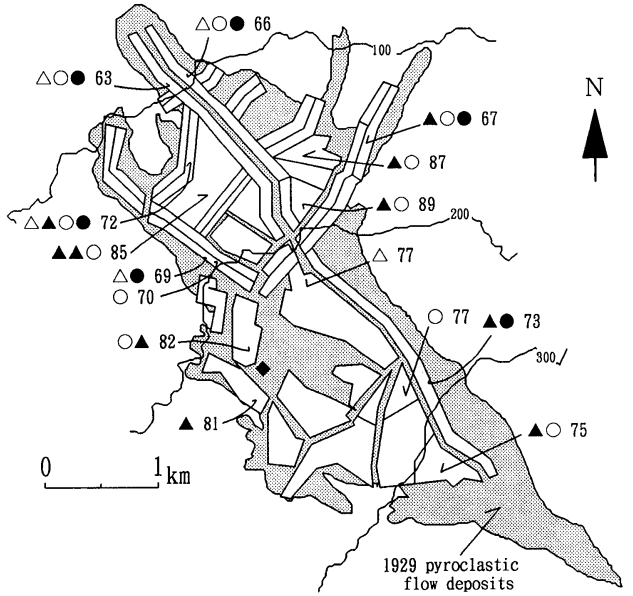

zii）およびハコネウツギ (Weigela coraeensis) の12樹種 にのぼっている。植栽地の概要を図 2 に示したが，植栽 年度ごとの帯状植栽地 (幅50 m) は幅10～20 m の帯状区 に分割され，植栽木はそれぞれの帯状区に樹種ごとに植
図 2 植栽地概要

Fig. 2 Location of Oshironai erosion control forests. Each symbol represents examined plots and species. Legend: $\triangle$, Pinus spp. (P. thunbergii, P. sylvestris) ; $\mathbf{\Delta}$, Larix spp. (L. leptolepis, L. gmelini) ; ○, Alnus hirsuta; ○, Betula platyphylla var. japonica; $>$, examined plot of secondary forests on the 1929 pyroclastic flow deposits. Numerals beside each symbol represent planting years.

栽されており，それらの間に再生林が島状に取り残され ている。植栽時にはブルドーザーによる火山礫の破砕と 起伏部の整地が行われた。また, 径 $50 \mathrm{~cm}$, 深さ $50 \mathrm{~cm}$ の 植栽穴には保水力の増加と施肥のため埋莕・客土などが 
施された。

調査地域の気候条件は，北西山麓では年降水量が 1120 $\mathrm{mm}$, 年平均気温が $8.3^{\circ} \mathrm{C}$, 積雪量が $1.0 \mathrm{~m}$, 南西山麓では それぞれ $1290 \mathrm{~mm}, 7.4^{\circ} \mathrm{C}, 1.0 \mathrm{~m}$ であり，双方ともほぼ 同様な気候条件にあると考えられ，道内では比較的温暖 な気候といえる。

\section{3. 調査方法}

調査は火砕流堆積物上の植栽地と自然回復による再生 林において以下の方法で行った。植栽地においては, 植 栽樹種ごとに標高別に同程度ずつ $2 \sim 4$ 年間隔で計 32 ケ 所の調査対象区を選び，それぞれに100〜 $200 \mathrm{~m}^{2}$ の方形 区を設定した（表 1 , 図 2 参照)。調査は植栽木の樹高, 胸高直径 (樹高 $1.3 \mathrm{~m}$ 末満のものは根元径), 生残本数を 調べた。また同時にそれぞれの方形区内に $5 \mathrm{~m} \times 5 \mathrm{~m}$ の プロットを取り，侵入した木本と草本の種類および高さ を調べた。また, 侵入木本を一部伐採し, 樹齢からその 侵入時期を調べた。なお，これら植栽地の比較対象とす るために, 同堆積物上の再生林から, 特に標準的と思わ れたところにおいて，10 m×10 m の方形区を 1 ケ所設 定し, すべての侵入木本について樹種, 樹高を測定し, ついで，切り取った円盤から樹歯を測定した。さらに， 森林が破壊されてからの経過年数の違いにより森林構造 が異なると考えられるため, 駒ケ岳南麓大沼周辺の 1640 年山体崩壊堆積地上に成立している森林において, 5 $\mathrm{m} \times 20 \mathrm{~m}$ の方形区を 1 ケ所設定し, 胸高直径 $1 \mathrm{~cm}$ 以上 の樹木について樹種, 樹高, 胸高直径および樹冠幅を測 定した。また, 植栽地内の主な方形区, 再生林および 1640 年堆積物上の森林において土壤調査を行い, 土壤断面図 をとった。さらに, $\mathrm{A}_{0}$ 層直下の土を採取し, 実験室に持
ち㷌り, 乾式燃焼法 (CN コーダー)により全炭素 (\%), 全窒素（\%）を測定した。以上の調查から, 植栽地と再 生林地の比較を行った。

\section{4. 結果と考察}

\section{1 火山性荒廃地上の再生林の構造}

4.1 .1 噴火後60年を経過した再生林の構造

1) 構成樹種と樹高

プロットに存在する侵入木は, カラマッ, ヤマナラシ (Populus sieboldii), シラカンバ, ヤナギ類\{バッコヤナ ギ (Salix bakko)，イヌコリヤナギ (S. integra)\}，ケヤ マハンノキ，ホツツジ (Tripetaleia paniculata)，ノリウ ツギ (Hydrangea paniculata) が認められた（表 2 )。イ ヌコリヤナギは匍伏性の灌木であり，その他はカラマツ を除いて北海道内に一般的にみられる先駆性広葉樹であ る。カラマツは北海道内には自生しておらず，噴火以前 から山麓周辺に植栽されたものを母樹として, 火砕流堆 積物上に種子を飛来させて繁殖したものと考えられる。 侵入数の約 $1 / 3$ はカラマツによって占められ, ついで, ヤ マナラシ, ヤナギ類の順となり，その他はわずかである。 樹高は $1 \mathrm{~m}$ までの小木が全体の約 $80 \%$ を占め, $3 \mathrm{~m}$ を超 えるものは稀である。林床はススキ (Miscanthus sinensis), ヤマハハコ (Anaphalis margaritacea) などがわず かに散生するに過ぎず，径 $20 \sim 30 \mathrm{~cm}$ 程度の軽石が裸出 している。

\section{2) 生長過程}

再生林内の $10 \mathrm{~m} \times 10 \mathrm{~m}$ の方形区内にみられた侵入木 の根元を切り取り年輪を判読し，樹高と樹齢の関係を図 3 に示した。侵入木全体での樹齢構成を見ると，樹齢は 最高で 46 年のものが認められたが，全体的には 20 年生以

表 2 北海道駒ケ岳1929年火砕流堆積地における侵入木本の樹高

Table 2 Number of invading trees in each height grade in the plot $(10 \mathrm{~m} \times 10 \mathrm{~m})$ on the 1929 pyroclastic flow deposits of Mt. Koma

\begin{tabular}{|c|c|c|c|c|c|c|}
\hline \multirow{2}{*}{ Species } & \multicolumn{5}{|c|}{ Height classes in $\mathrm{m}$} & \multirow{2}{*}{$\frac{\text { Tatal }}{\left(\text { No. } / 100 \mathrm{~m}^{2}\right)}$} \\
\hline & $0 \sim 0.4$ & $0.4 \sim 1$ & $1 \sim 2$ & $2 \sim 3$ & $3 \sim$ & \\
\hline Larix sp. & 28 & 14 & 5 & 1 & & 48 \\
\hline Populus sieboldii & 3 & 19 & 14 & 2 & 1 & 39 \\
\hline Betula platyphylla var. japonica & 1 & 19 & 7 & 1 & 1 & 29 \\
\hline Salix bakko & 3 & 12 & 4 & & & 19 \\
\hline Salix integra & 7 & 5 & & & & 12 \\
\hline Tripetaleia paniculata & 6 & 1 & & & & 7 \\
\hline Hydrangea paniculata & 1 & 2 & & & & 3 \\
\hline Alnus hirsuta & & 1 & & & & 1 \\
\hline Total (No. $\left./ 100 \mathrm{~m}^{2}\right)$ & 49 & 73 & 30 & 4 & 2 & 158 \\
\hline
\end{tabular}




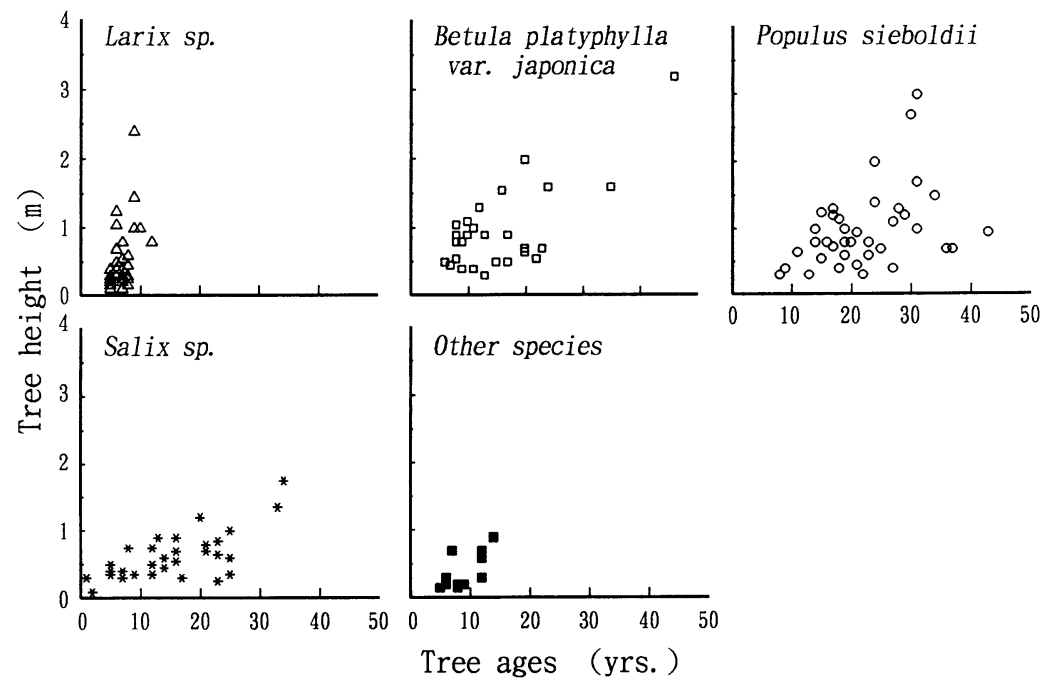

図 3 1929年火砕流堆積物上の再生林における樹種別の樹齢と樹高

Fig. 3 Age and height of invaded trees on the 1929 pyroclastic flow deposits

下のものが多かった。樹種別に検討すると, カラマツで は10年生以下が $90 \%$ 含まれ, 最近著しく個体数が増加し てきていることがわかった。ヤマナラシは樹齢10〜40年 の間にほぼ一様に分布しており，シラカンバについては 46 年生のものが 1 本あるが，全体的には $5 \sim 30$ 年の中に 含まれる。ヤナギ類についても 30 年を超えるものは稀で, ほぼ10３0年の間に分布することがわかった。

次に樹齢と樹高の関係をみると，カラマツは樹齢と樹 高生長がほぼ比例関係にあり，樹齢の大きいものが樹高 も高くなっている。しかし, 広葉樹類はバラツキが大き く, 個体数が最も多いヤマナラシは 20 年, $2 \mathrm{~m}$ 前後で樹高 生長が頭打ちになり，これ以降20～30年経過しても $2 \mathrm{~m}$ を超えるものは少ない。シラカンバもヤマナラシとほぼ 同様に, 10〜30年までにランダムに分布するが, $3 \mathrm{~m}$ に達 するものはほとんどない。ヤナギ類は樹高生長が小さく, 30 年生以下はその $90 \%$ が樹高 $1 \mathrm{~m}$ 以下であった。また生 育形態について,カラマツには主だった損傷はみられず, 健全な生長を示していたが，ヤマナラシ，シラカンバを はじめとする広葉樹類では, 先枯れ, 幹折れ-萌芽などの 損傷が顕著に認められた。

以上の結果から, 広葉樹類の樹高生長が頭打ち, ない しは衰退傾向であること, また, カラマツの著しい増加 と上長生長が特徵的であるといえる。全体的には, 火砕 流堆積物上では自然状態での植生の回復は遅く，林床は 軽石が堆積しており，森林を形成するにはさらに長い時 間を要するものと思われる。

\section{1 .2 噴火後350年を経過した森林の構造}

1640 年山体崩壊堆積物上に成立している再生林内の, $5 \mathrm{~m} \times 20 \mathrm{~m}$ の方形区内にみられた胸高直径 $1 \mathrm{~cm}$ 以上の 侵入木は, コナラ (Quercus serrata), ミズナラ (Q. mongolica var. grosseserrata), イタヤカエデ (Acer mono), アズキナシ (Sorbus alnifolia) など 9 樹種であ る(表 3 )。本数的には, イタヤカエデ, コナラ, ミズナ ラがその過半を占めている。樹高に関しても $10 \mathrm{~m}$ 以上の ものではこれら 3 種が 8 割を占め, ミズナラでは $20 \mathrm{~m}$ を 超すものもみられ, 典型的なイタヤカエデ・コナラ林分 である。これらの側面図および樹冠投影図を図 4 に示し た。4.1.1に前述したカラマツ主体の再生林においても, 300 年後にはこのようなイタヤカエデ, コナラなどが優占 する広葉樹林へと移行するものと思われる。

\section{2 植栽地の生育状況}

\subsection{1 植栽木の樹高, 直径生長}

植栽地におけるクロマツ類（ヨーロッパアカマツを含 む), カラマツ類（グイマツを含む），ケヤマハンノキお よびシラカンバの樹高, 胸高直径と経過年数の関係を図 5 , 表 4 に示した。全体的に経過年数が多いほど樹高が 高く, 直径も大きくなっている。植栽後 10 年ですでに再 生林の最高樹高 $(3 \mathrm{~m})$ を超えており，20年で $6 \mathrm{~m} ， 25$ 年 で最高 $10 \mathrm{~m}$ に達する。しかし，これ以降はやや減衰傾向 にあり，生長が頭打ちになった。樹種的にみると，最も 樹高が高く生長がよいのはカラマツ類であり, ついで, ハンノキ，クロマツ類になっている。カラマツ類は 10 年 
表 3 北海道駒ケ岳 1640 年山体崩壊堆積地における侵入木本の樹高

Table 3 Number of invading trees in each height grade in the plot $(5 \mathrm{~m} \times 20 \mathrm{~m})$ on the 1640 debris avalanche deposits of Mt. Koma

\begin{tabular}{|c|c|c|c|c|c|c|c|}
\hline \multirow{2}{*}{ Species } & \multicolumn{6}{|c|}{ Height classes in $\mathrm{m}$} & \multirow{2}{*}{$\frac{\text { Total }}{\left(\text { No. } / 100 \mathrm{~m}^{2}\right)}$} \\
\hline & $0 \sim 2$ & $2 \sim 5$ & $5 \sim 10$ & $10 \sim 15$ & $15 \sim 20$ & $20 \sim$ & \\
\hline Acer mono & & 3 & 1 & 2 & & & 6 \\
\hline Quercus serrata & 2 & & & 1 & 2 & & 5 \\
\hline Quercus mongolica var. grosseserrata & & 1 & & & 1 & 2 & 4 \\
\hline Sorbus alnifolia & & 1 & 1 & 1 & & & 3 \\
\hline Prunus sargentii & & 1 & & 1 & & & 2 \\
\hline Tilia japonica & & 1 & 1 & & & & 2 \\
\hline Maakia amurensis var. buergeri & & & 1 & & & & 1 \\
\hline Pinus koraiensis & & 1 & & & & & 1 \\
\hline Hydrangea paniculata & 1 & & & & & & 1 \\
\hline Total $\left(\mathrm{No} . / 100 \mathrm{~m}^{2}\right)$ & 3 & 8 & 4 & 5 & 3 & 2 & 25 \\
\hline
\end{tabular}
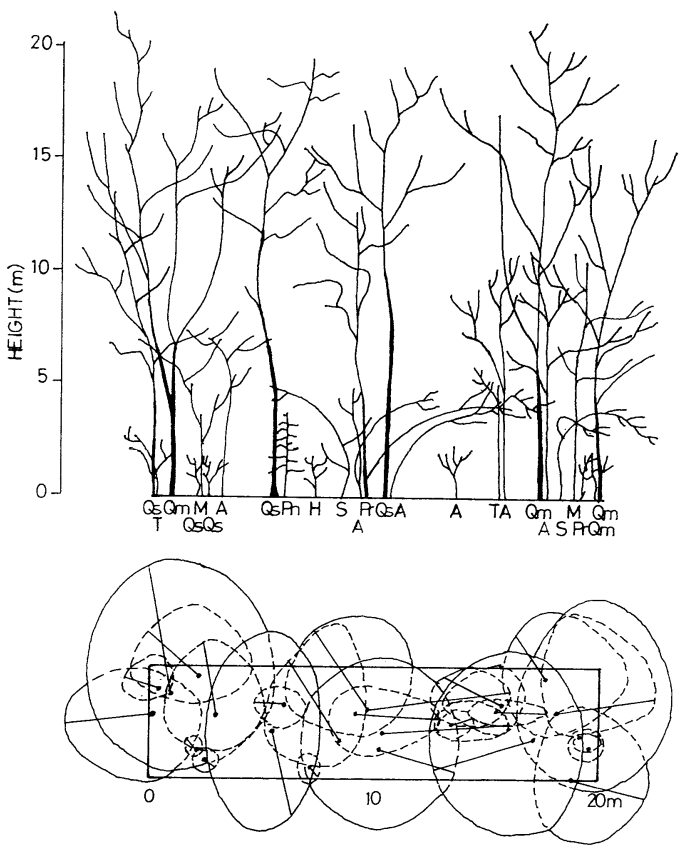

図 4 1640年山体崩壊堆積物上に成立している森林の側 面図および樹冠投影図

図示された木はいずれも胸高直径 $1 \mathrm{~cm}$ 以上。

Fig. 4 Profile and crown projection of the secondary forest on the 1640 debris avalanche deposits. Trees presented in the profile and crown projection are above $1 \mathrm{~cm}$ in D.B.H., respectively. Legend: A, Acer mono; H, Hydrangea paniculata; M, Maakia amurensis var. buergeri; Pn, Pinus koraiensis; Pr, Prunus sargentii; Qm, Quercus mongolica var. grosseserrata; Qs, Quercus serrata; S, Sorbus alnifolia; T, Tilia japonica.
までは $2 \mathrm{~m}$ 前後と生長は良くないが, 徐々に生長量が大 きくなり，15～25年で 4 〜 $10 \mathrm{~m}$ に達する。このカラマツ は同堆積物上の再生林方形区でも侵入木の大部分を占 め, 生長も極めて良かったが, 植栽木においても同様で, 火山礫地带に適した樹種であるといえる。ハンノキやク ロマツ類では20年前後までは生長が良く 6 ～ $8 \mathrm{~m}$ に達 するが, その後生長量は徐々に低下する。これは後で述 べるように，樹体の枯れ上がりや幹折れなど生理的・物 理的な障害によるものが多い。カンバ類は樹高, 直径生 長ともに極めて悪く, 20 年で $2 \mathrm{~m}$ 前後のものもみられ た。

\section{2 .2 植栽木の生育形態}

単位面積当たりの植栽本数（初期植栽密度）に対する

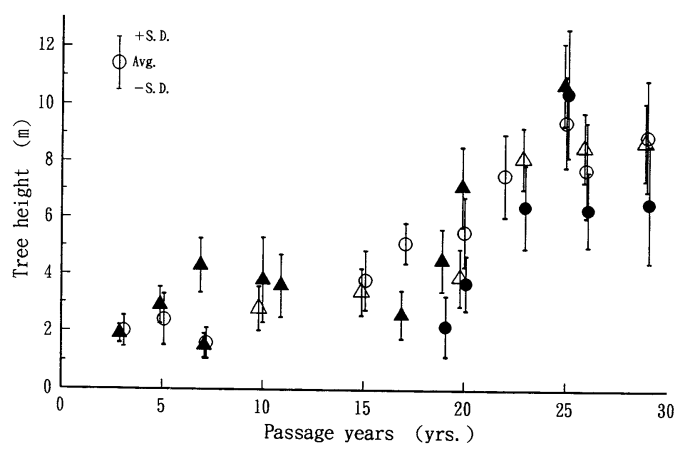

図 5 植栽木の平均樹高および標準偏差

Fig. 5 Height growth in planted tree species Legend: $\triangle$, Pinus spp. (P. thunbergii, $P$. sylvestris); $\mathbf{\Delta}$, Larix spp. (L. leptolepis, $L$. gmelini) ; $\bigcirc$, Alnus hirsuta; O, Betula platyphylla var. japonica. 
表 4 樹種ごとの年度別平均樹高および平均直径

Table 4 Height and D.B.H. of planting trees

\begin{tabular}{|c|c|c|c|c|}
\hline \multirow{2}{*}{ Sp. } & \multirow{2}{*}{$\begin{array}{l}\text { Planting } \\
\text { years }\end{array}$} & \multirow{2}{*}{$\begin{array}{l}\text { Passage } \\
\text { years }\end{array}$} & \multirow{2}{*}{$\frac{\text { Mean height } \pm \mathrm{SD}}{(\mathrm{m})}$} & \multirow{2}{*}{$\begin{array}{c}\text { Mean D.B.H. } \pm \text { SD } \\
(\mathrm{cm})\end{array}$} \\
\hline & & & & \\
\hline \multirow{6}{*}{ Pinus spp. } & 1963 & 29 & $8.7 \pm 1.38$ & $13.5 \pm 3.43$ \\
\hline & $1966 \mathrm{Psl}$ & 26 & $8.5 \pm 1.24$ & $10.6 \pm 3.36$ \\
\hline & 1969 Psl & 23 & $8.1 \pm 1.10$ & $12.5 \pm 3.19$ \\
\hline & 1972 & 20 & $3.9 \pm 1.00$ & $6.5 \pm 2.52$ \\
\hline & 1977 & 15 & $3.4 \pm 0.82$ & $5.9 \pm 1.81$ \\
\hline & 1982 & 10 & $2.8 \pm 0.76$ & $3.7 \pm 1.63$ \\
\hline \multirow{10}{*}{ Larix spp. } & 1967 & 25 & $10.7 \pm 1.42$ & $14.3 \pm 3.01$ \\
\hline & 1972 & 20 & $7.1 \pm 1.42$ & $10.8 \pm 3.60$ \\
\hline & 1973 & 19 & $4.5 \pm 1.10$ & $6.8 \pm 2.28$ \\
\hline & 1975 & 17 & $2.6 \pm 0.83$ & $3.6 \pm 1.27$ \\
\hline & 1981 & 11 & $3.6 \pm 1.09$ & $4.4 \pm 1.55$ \\
\hline & $1982 \mathrm{Lg}$ & 10 & $3.8 \pm 1.49$ & $4.2 \pm 2.44$ \\
\hline & 1985 & 7 & $4.3 \pm 0.96$ & $4.8 \pm 1.49$ \\
\hline & $1985 \mathrm{Lg}$ & 7 & $1.5 \pm 0.42$ & $0.9 \pm 0.65$ \\
\hline & $1987 \mathrm{Lg}$ & 5 & $2.9 \pm 0.64$ & $2.6 \pm 0.98$ \\
\hline & $1989 \mathrm{Lg}$ & 3 & $1.9 \pm 0.31$ & $1.1 \pm 0.37$ \\
\hline \multirow{10}{*}{ Alnus hirsuta } & 1963 & 29 & $8.9 \pm 1.97$ & $10.9 \pm 2.10$ \\
\hline & 1966 & 26 & $7.7 \pm 1.69$ & $10.4 \pm 2.18$ \\
\hline & 1967 & 25 & $9.4 \pm 1.60$ & $9.8 \pm 2.52$ \\
\hline & 1970 & 22 & $7.5 \pm 1.47$ & $10.9 \pm 2.75$ \\
\hline & 1972 & 20 & $5.5 \pm 1.22$ & $7.8 \pm 2.75$ \\
\hline & 1975 & 17 & $5.1 \pm 0.71$ & $6.4 \pm 1.55$ \\
\hline & 1977 & 15 & $3.8 \pm 1.03$ & $5.1 \pm 2.13$ \\
\hline & 1985 & 7 & $1.6 \pm 0.53$ & $1.0 \pm 0.65$ \\
\hline & 1987 & 5 & $2.4 \pm 0.89$ & $2.1 \pm 1.28$ \\
\hline & 1989 & 3 & $2.0 \pm 0.54$ & $1.3 \pm 0.88$ \\
\hline \multirow{6}{*}{$\begin{array}{l}\text { Betula } \\
\text { platyphylla } \\
\text { var. japonica }\end{array}$} & 1963 & 29 & $6.5 \pm 2.08$ & $6.6 \pm 2.19$ \\
\hline & 1966 & 26 & $6.3 \pm 1.33$ & $5.9 \pm 1.74$ \\
\hline & 1967 & 25 & $10.4 \pm 2.24$ & $10.2 \pm 3.29$ \\
\hline & 1969 & 23 & $6.4 \pm 1.47$ & $6.0 \pm 1.99$ \\
\hline & 1972 & 20 & $3.7 \pm 0.95$ & $3.3 \pm 1.17$ \\
\hline & 1973 & 19 & $2.2 \pm 1.05$ & $2.4 \pm 1.40$ \\
\hline
\end{tabular}

Notes: In Pinus spp. and Larix spp., Psl and Lg represent Pinus sylvestris and Larix gmelini, others are Pinus thunbergii, Larix leptolepis.

生残本数の割合を植栽樹木の生残率とし,図 6 に示した。 植栽から10年前後まで経過したもの（初期植栽密度 4 〜 5 千本/ha)の多くは70\%以上と高い生残を示す。しか し15〜20年ほど経過したもの（同 5 〜 6 千本/ha）は 40 $80 \%$ とバラツキが大きい。クロマツ類やハンノキで は植栽密度別にみても生残率は低いが，シラカンバ（同 6 千本/ha)において高い值のものも認められる。さらに 25 年以上経過したもの (同10千本/ha) では全樹種ともに $40 \%$ 以下の值を示す。特にハンノキでは生残率は低くな り, 逆にシラカンバではやや高い值を示し, 樹高生長と
は逆の傾向を示している。これはハンノキなどでは樹高 生長・被陰効果が大きいために, 生長の悪いものは枯死 したが，シラカンバでは生長が悪くそれほど被陰されな いため, 多くの個体が残存したものと解釈される。

上述した植栽木の生長阻害形態には, 生理的障害によ る先枯れ, 物理的な風による幹折れ, 萌芽などがみられ る。調查した生残木本数に対する障害木本数の割合を植 栽樹木の損傷率とし, 図 7 に示した。全体的には植栽後 経過年数の長いものほど損傷率が高くなっており, 樹種 的な差も著しい。植栽後10年までは損傷率は $20 \%$ 以下で 
あるが，15年を経過して急激に損傷が進み，20年を経過 した時点で $70 \%$ に達するものもある。特にシラカンバは 損傷が著しく，そのほとんどが幹折れ，先折れおよび先 枯れなどの生理的・物理的な損傷を受けていた。またケ ヤマハンノキは10 30\%程度の損傷であったが，形態的 には先枯れの損傷が多かった。やや高標高に植えられた カラマツには, 駒ケ岳からの吹き下ろし風による梢頭部

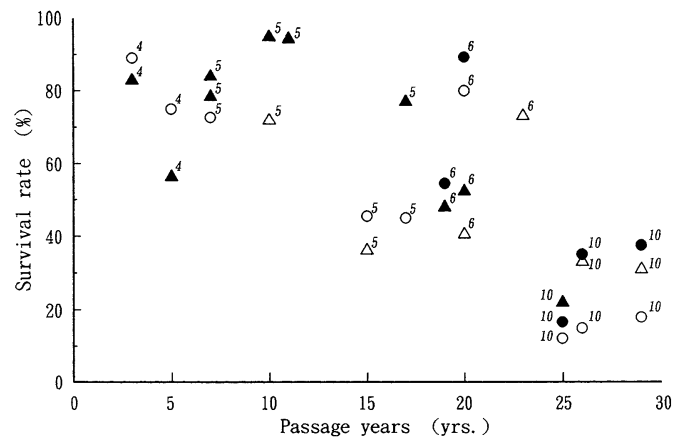

図 6 植栽木の生残率

Fig. 6 Survival rates (S.R.) in planted trees. S.R.= (No. of remaining trees/No. of planted trees) $\times 100$. For each symbol, refer to Fig. 5 . Numerals above each symbol represent planting density (1000/ha).
の枯損が多くみられた。さらにヨーロッパアカマッ，ク ロマツでは風倒による根返りの被害が著しく, 火砕流堆 積地での根張りの浅さが原因と思われる。

\section{2 .3 植栽地への植生侵入}

方形区内の調査プロット $(5 \mathrm{~m} \times 5 \mathrm{~m}) 32$ ケ所で出現し た樹種と密度 $\left(5 \mathrm{~m} \times 5 \mathrm{~m}\right.$ を $100 \mathrm{~m}^{2}$ 亿換算 $)$ を図 8 に示 す。出現種はカンバ類，ヤナギ類，カラマツ，クロマツ,

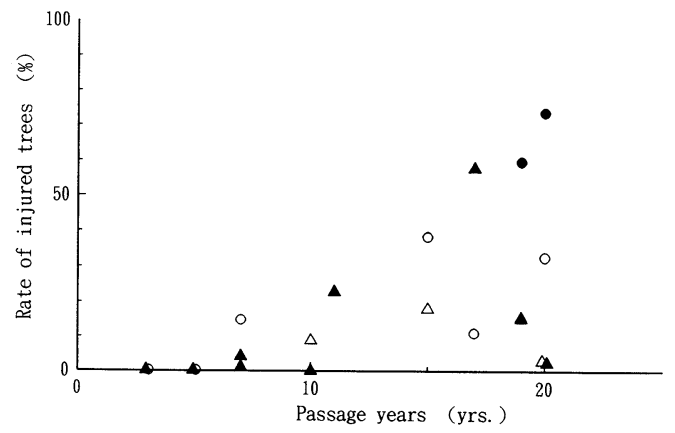

図 7 植栽木の損傷率

Fig. 7 Rates of injured trees (R.I.) in planted trees. R.I. $(\%)=($ No. of injured trees $/$ No. of examined trees) $\times 100$. For each symbol, refer to Fig. 5.

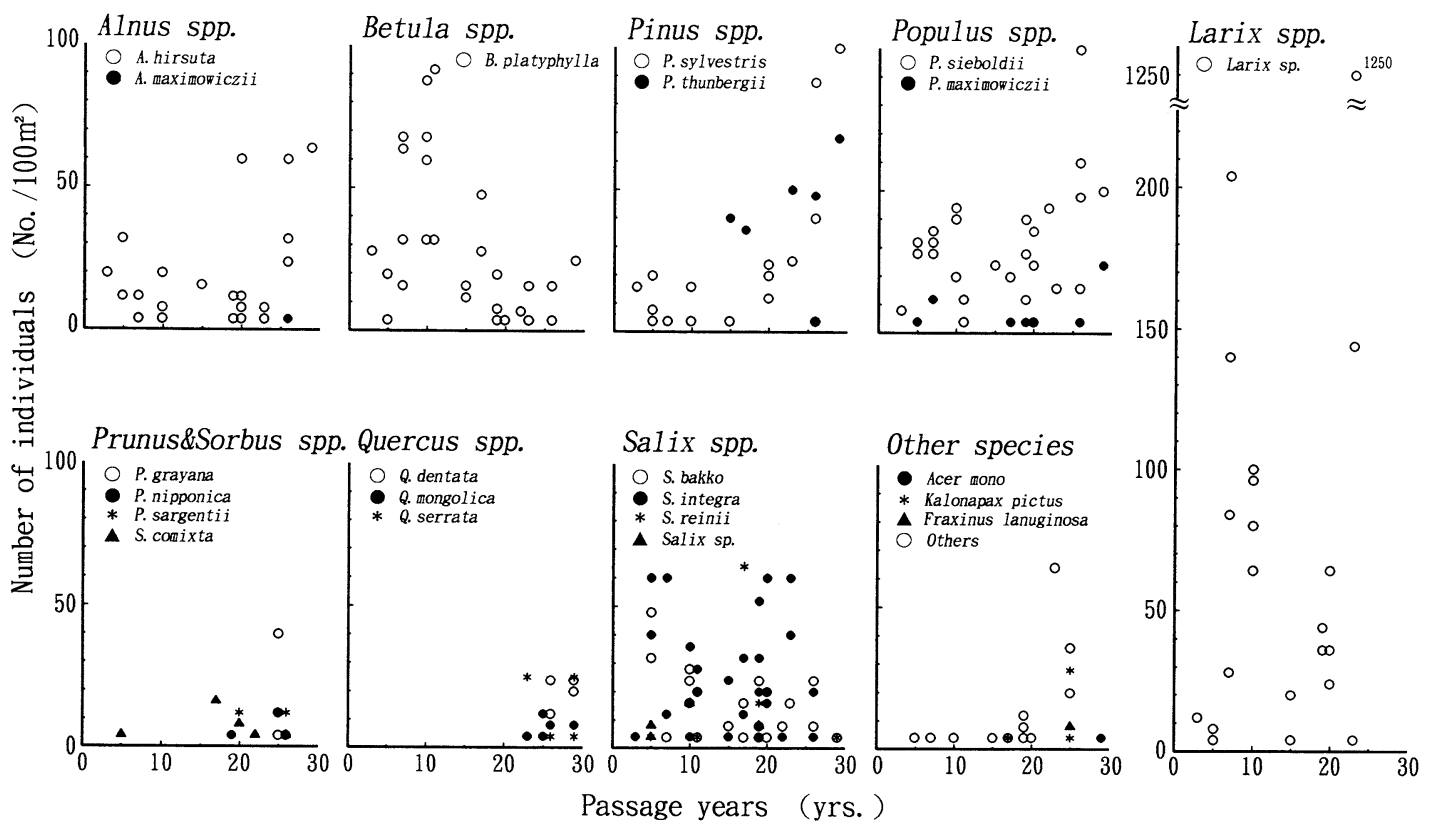

図 8 植栽地における侵入樹種ごとの侵入密度

Fig. 8 Number of invaded trees on the planted area 
アカマツ (ヨーロッパアカマツ) およびコナラ類など 36 樹種に及ぶ。そのうちシラカンバ, カラマツが15年以下 の若い植栽地に $60 \sim 130$ 本 $/ 100 \mathrm{~m}^{2}$ の密度で出現するが,

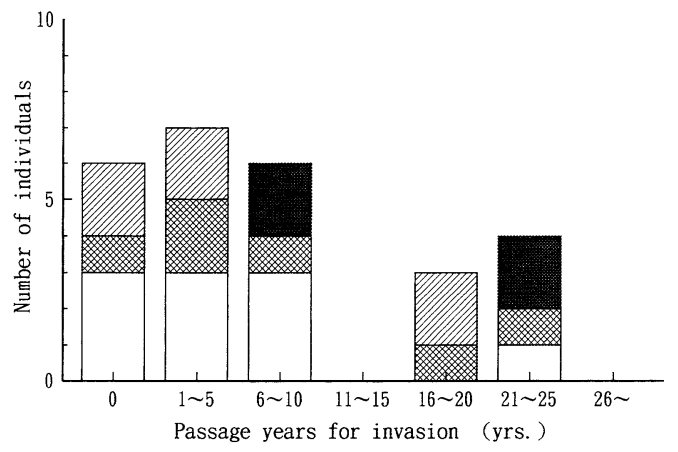

図 9 樹種別侵入時期

Fig.9 Frequency distribution of passage years for invasion after plantation

Legend: $\square$, Alnus hirsuta, Betula platyphylla var. japonica; , Salix spp., Populus maximowiczii; 爵, Larix sp., Pinus spp.; 口, Quercus dentata, Acer palmatum.
20 年を経過してからは 0.4 本 $/ 100 \mathrm{~m}^{2}$ 以下と減少する。こ れは樹冠の欝閉により，これらの幼樹が生育できなくな るためと思われる。また, カラマツは火山礫が裸出して いるところに多く出現していた。その他ヤマナラシ, ヤ ナギ類といった先駆性広葉樹類は 30 年を通して高密度に 出現していた。一方コナラ類は, 植栽後 20 年以降の植栽 地に多く出現していたが, これらは周辺の母樹群からネ ズミや鳥などの動物によって散布されたものと思われ る。その他ナナカマド (Sorbus commixta) など鳥によっ て散布される樹種もみられるようになり, 周辺に樹林が あることによる動物に付随した効果もみられるようにな る。次に侵入木を一部伐採し，その樹齢から侵入時期を 求めた(図 9 )。それによるとシラカンバ，ハンノキ，ヤ ナギ類およびカラマツなどの先駆性樹種の約 8 割は植栽 後 10 年以内に侵入・定着しているものであった。一方, ミズナラ, カシワ (Quercus dentata) などのコナラ類は 植栽後 10 年ほどで侵入したものもみられたが, その多く は20年以上経過した後に定着したものであった。また侵 入草本については, ススキ, ヤマハハコ, オオイタドリ (Reynoutria sachalinensis), オオヨモギ (Artemisia
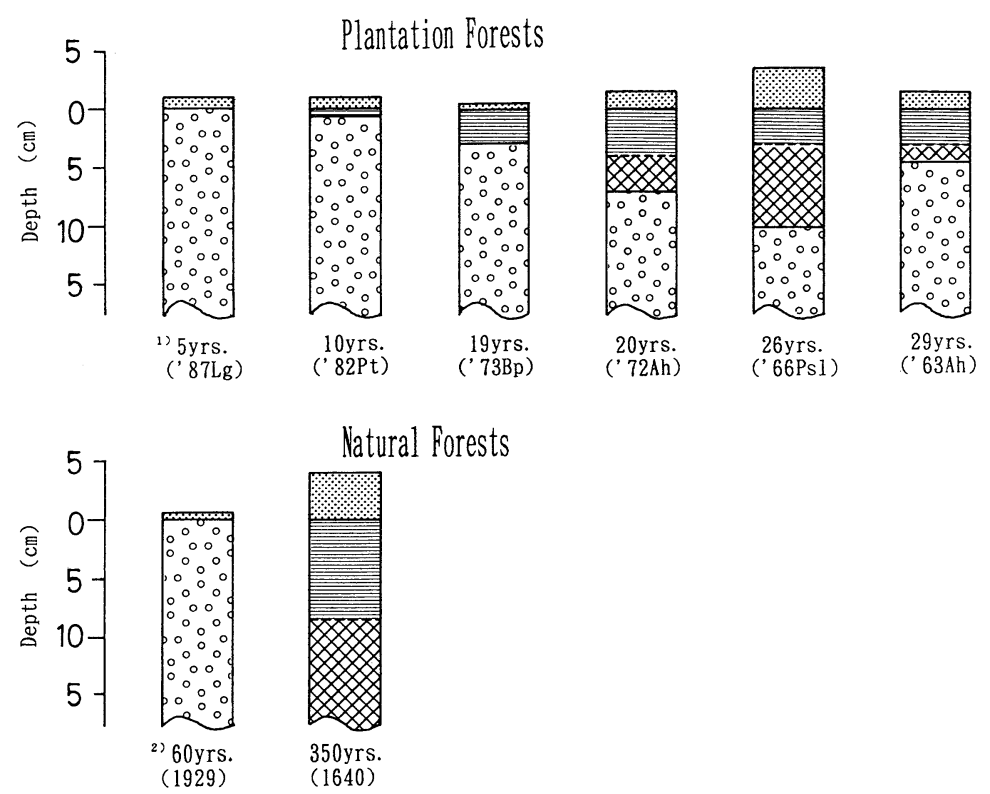

図10 植栽地および再生林における土壌断面図

Fig. 10 Soil profiles of the plantation forests and secondary forests on the volcanic devastated areas. Legend : $\mathrm{A}_{0}$ horizon; $\mathrm{A}$ horizon; $\mathrm{B}$ horizon; years after plantation, and planting years and abbreviations are indicated in parentheses below them. Ah, Alnus hirsuta; Bp, Betula platyphylla var. japonica; Lg, Larix gmelini; Psl, Pinus sylvestris ; Pt, Pinus thunbergii. 2) Numerals above represent passage years after eruption of Mt. Koma., and years of eruption are indicated in parentheses below them. 
montana), アキタブキ(Petasites japonicus subsp. giganteus) が多くみられ, 経過年数が長いプロットほど 草本全体の被度は高い値を示していた。以上のことから, 樹冠が閉鎖されるまでは, ヤナギ類, ヤマナラシ, カン バ類などの先駆性広葉樹が多く侵入, 定着しているが, 時間を経るにしたがってそれらの樹種は減少し，20年を 経過して以降, ミズナラ, カシワ, ナナカマドなど動物 によって種子が運ばれる樹種も定着するようになり, 全 体の種数としても増加する傾向がみられた。

\subsection{4 林地の土壊化}

各調査対象区が同一火研流堆積物上にあること,また， 植栽時に同様に火山礫の破砕抢よび整地を行っているこ とから, 植栽前の地表条件は同一とみなせるため, 植栽 樹種や植栽年度（経過年数）が土壤構造・成分に大きく 影響するものと思われる。

主な植栽地および再生林の土袞構造を図10に示した。 植栽後 10 年以下のプロットでは $\mathrm{A}$ 層の発達はみられず, リ夕ー層 $\left(\mathrm{A}_{0}\right.$ 層) の集積も少なく, $\mathrm{A}_{0}$ 層直下に赤褐色の 火砕流堆積物がみられた。植栽後 10 20年経過した場合 でも, ハンノキにおいて $2 \sim 3 \mathrm{~cm}$ の $\mathrm{A}_{0}$ 層および数 $\mathrm{cm}$ の暗褐色の $\mathrm{A}$ 層が発達するのみである。20年を経過した 植栽地注いても同様に, ハンノキのみでやや厚い $\mathrm{A}$ 層 がみられた。針葉樹の植栽地では分解があまり進まず， $2 \mathrm{~cm}$ 程度の $\mathrm{A}_{0}$ 層が林床に堆積する。一方, 再生林にお いては，60年経過したにも関わらず， $1 \mathrm{~cm}$ 程度の $\mathrm{A}_{0}$ 層 が堆積しているにすぎず, 土壤化は進んでいない。しか し 350 年経過した再生林では, $4 \mathrm{~cm}$ ほどの $\mathrm{A}_{0}$ 層の下に $10 \mathrm{~cm}$ ほどの $\mathrm{A}, \mathrm{B}$ 層が形成されており, 土袞化が進んだ ものと思われる。

また, 火砕流堆積物上に植栽した結果, 土境構造およ び成分がどのように変化したかをみるために, 土壌厚 ( $\mathrm{A}_{0}$ 層およびA層) および全炭素 (\%), 全窒素 (\%)，C/ $\mathrm{N}$ 比の時間的推移を図11に示す。ここでは同堆積物上に 新たに形成されたものに注目したため, $\mathrm{A}_{0}$ 層および $\mathrm{A}$ 層 双方あわせた土壌厚の值を示したところ, いずれも経過 年数に従い土壌厚が増しているが, 他の 3 種に比べてケ ヤマハンノキが高い値を示す傾向がみられる。全炭素 (\%)については, 植栽後 20 年ほどまでのクロマツ類, カ ラマツ類, ケヤマハンノキでは， $3 \%$ 以下と非常に低い 值を示している。ケヤマハンノキでは15年過ぎから, 他 の 3 種では 20 年過ぎからその割合は急激に増加し, 高い ものでは15\%近いものもある。全室素（\%）についても 全炭素と同様な傾向を示し，15～20年過ぎから急激に高 い值を示すようになる。 $\mathrm{C} / \mathrm{N}$ 比に関しては全体的にやや 右下がりで時間とともに低下する傾向にあり，10２0程

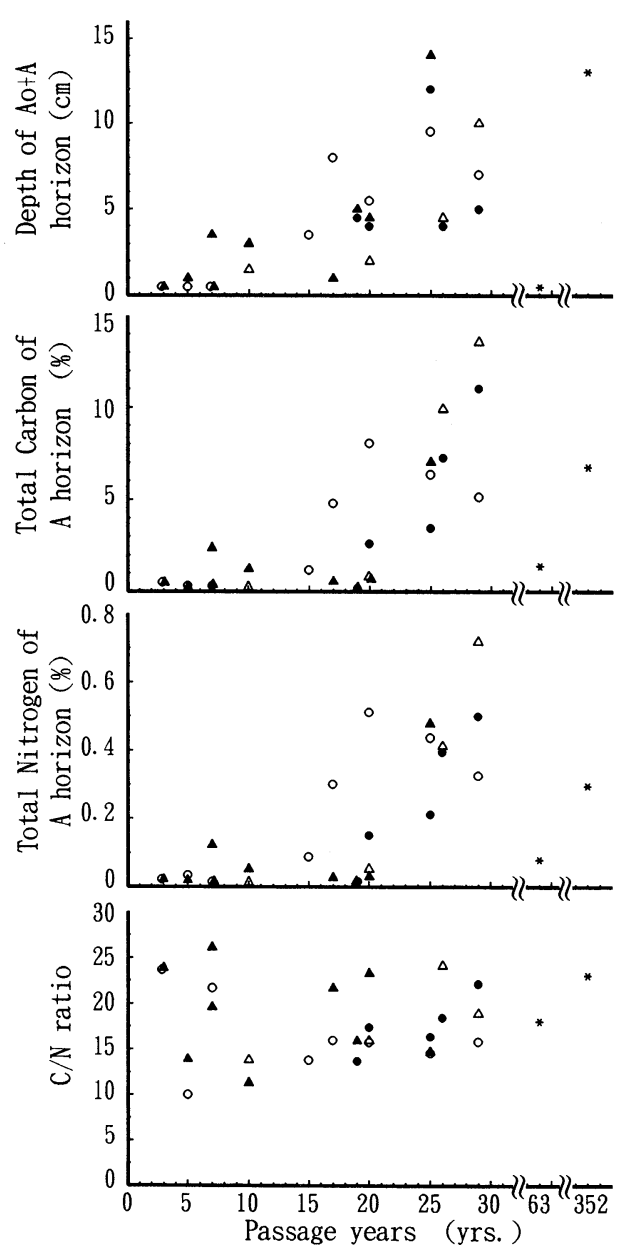

図11植栽地および再生林の土壎厚および C, N値

Fig. 11 Soil conditions of tree plantation areas in each planting year and secondary forests.

For each symbol except for $*$, refer to Fig. 5 . $*$ represent secondary forests on the devastated areas by eruptions of Mt. Koma in 1929 (63yrs.) and 1640 (352yrs.).

度に収斂するものとみられた。全体的にみると,ケヤマ ハンノキで炭素 (有機物), 窒素の供給が盛んであるが, カラマツ類ではそれが低く, クロマツ類, シラカンバで はその中間的であることがわかった。一方再生林におい ては，噴火後60数年経過しているにも関わらず，いずれ も低い值を示し,土袞化が進んでいないことがわかった。

\section{3 植生の回復過程と森林造成の意義}

\subsection{1 植生の回復過程}

今回の調査結果と過去の植生記載, 7,15$)$ とをあわせ, 火 砕流堆積地の植生回復過程を検討してみる。 
堆積地形成直後には, ワラビ, オオイタドリ, オオブ キ，ススキなどの多年生草本が侵入・発生した。 $4 \sim 5$ 年経過してから, 火山噴火による被害の少なかった森林 (島状地) から種子が飛来し, イヌコリヤナギ, ミネヤナ ギ, バッコヤナギ, ヤマナラシ, シラカンバ, ウダイカ ンバ,ノリウツギ, ナナカマドなどの稚樹が確認されて いる。これらの大部分の種子は, 羽毛のついた軽量の風 散布型種子であり, 裸地面積の広大な火山性荒廃地にお いて, 初期侵入条件に見合ったものばかりである。噴火 後10年を経過した時点では, 木本の侵入が目立って増加 しており，その中で優勢を占めるのがバッコヤナギ， シ ラカンバ, ドロノキの 3 種であり, 草本では, ススキ, アキタブキ, オオイタドリの大型草本であった。その他, コケ類の侵入が記載されている。

形成後 20 年を経過した1948年には,木本ではドロノキ, カンバ類が増加しているが, バッコヤナギ, イヌコリヤ ナギは横這いかやや減少する傾向がみられた。また樹高 も, ドロノキ, シラカンバでは $2 \sim 3 \mathrm{~m}$ に達するものも みられたが, ヤナギ類はほとんど生長していない。 40 年 後の植生実態については, 館脇（1966）の詳細な調査に よると, 火砕流堆積地の山麓下部ではドロノキ林, ある いは, ドロノキ, シラカンバを主とする群落によって構 成されていた。

今回の調査の結果, こうした在来の広葉樹類は生長が 頭打ちで, 変わってカラマツが優勢を占めつつある。す なわち, 先駆性広葉樹類は噴火後早期に森林を形成する が, その後, 侵入と衰退を繰り返して今日に至っている ことがわかった。一方カラマツは, 北海道の自生種では ないが, 近年著しく増加しており, 樹高と樹齢構成など
からみて, 今後カラマツを主体とする森林が形成されて いくものと思われる。

\subsection{2 活火山山麓における森林造成の意義}

活火山山麓では, 火砕流・溶岩流あるいは火山灰降下 などによる森林消失跡地に, 独特の純林状の再生林が観 察され, それらの森林構造の特質が火山活動履歷を表し ていることが指摘されている（樽前山：新谷・西山, 1989 ; 十勝岳 : 新谷ら, 1991 ; 有珠山：柳井, 1981)。し かし, 火山性荒廃裸地に自然回復によって森林が再生す るためには, 長大な時間を要し, この間, 周辺下流域, 特に沿岸養殖漁場を抱える火山体では, 細粒土砂流出被 害は継続する。そこで, 良好な水産漁場への被害を軽減 させるために行われた駒ケ岳山麓の植栽地は以下のよう に評価される。

人為的に植栽したカラマツでは, 植栽後 25 年ですでに 樹高 $10 \mathrm{~m}$ を超える林が形成され, 再生林と比較して全く 異なる構造となっており, 自然状態で60年を経過して形 成できなかった過程をすでに20～30年で達成しているこ とがわかった。また，20年以上経過した植栽地内には， ミズナラ, カシワなど周辺の極相種的な樹木の稚樹も多 く侵入, 定着しており, 最終的には大沼周辺における約 350 年前の山体崩壊堆積物上に見られるようなミズナラ を主体とする広葉樹林（図 4 参照）へと緩やかに移行し ていると考えられる。一方，20年を経過した植栽木は， 先枯れ, 幹折れなどの損傷が著しく, 樹高生長が限界に 達しているようである。また土壌に関しては， $\mathrm{A}_{0}$ 層・A 層厚, 全炭素 (\%), 全窒素 (\%)ともに, 時間経過に伴 い高い值を示している。これについては, 堆積直後の火 砕流堆積物は極めて侵食されやすく，地表の安定化が遅

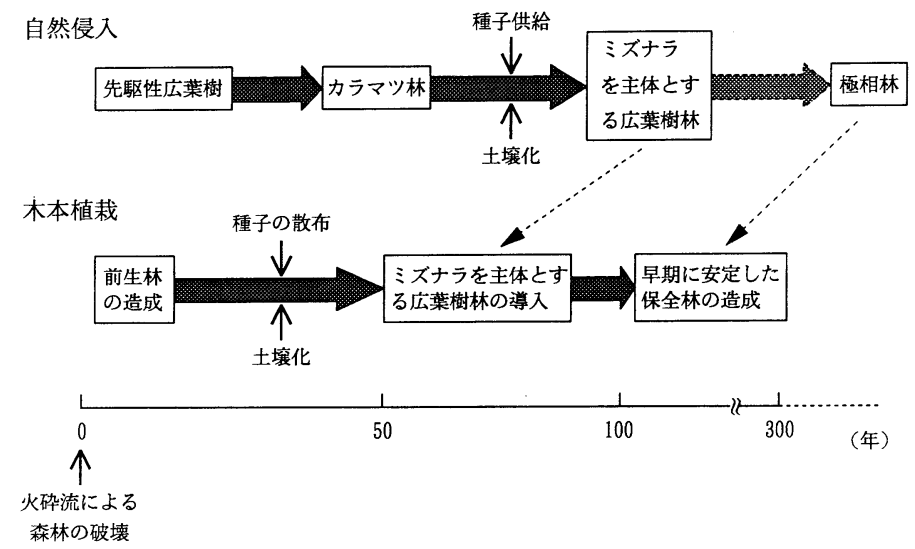

図12 火砕流堆積地での森林形成過程と木本導入の意義

Fig. 12 Forest recovery process and significance of tree planting on the pyroclastic flow deposits 
れるため ${ }^{16)}$, 侵入植生も種子流亡などにより定着が困難 であり, 植生回復には時間がかかり, 結果として土壤発 達も遅れると考えられる。これに対し, 火砕流堆積物上 に木本を植栽することにより表土の安定化をはかり，さ らに, 植栽木の生長に伴い, 地表への落葉落枝の供給が 継続されるため, 上述したような土壤化が促進されるで あろうと推測される。したがって, 火砕流堆積物上に木 本を植栽することにより, 樹木による地上空間構造なら びに表土の植生被覆および土壌化が促進され, 自然状態 より早期に森林を造成するという第一義的な目的は達成 されているといえよう（図12）。

以上のことから, 自然状態で植生回復が困難な場所で, このような砂防林を造成することにより, 森林化へのプ ロセスを大きく促進させ, 早期に活火山山麓を安定した 森林空間に造り上げることが可能となることがわかっ た。今後は, 衰退しつつある植栽林をいかに速く次のス テージである広葉樹林へと移行させていくかが大きな課 題である。広葉樹林の主体となり得るミズナラなどは種 子が大きく, その侵入は基本的には種子の供給条件（母 樹位置, 動物の存在など）に左右されるため, 人為的な 種子の散布や補植などが有効であろう。これらの具体的 な手法については, 今後さらに検討していきたいと考え ている。

\section{参考文献}

1）新谷 融・西山泰弘：樽前山山麓の土砂害防止に関する 研究, 北大演研報46(2)，271-285，1989

2）新谷融・清水 収・西山泰弘：十勝岳火山山麓におけ る火山泥流と土砂害の発生履歴に関する研究, 北大演研 報48(1)，191-232，1991
3）東 三郎：地表変動論, 北大図書刊行会, pp. 280, 1979

4) 岩川幹夫：混播における木本植物の成立 (I), 治山 $\mathbf{1 7}(2), 43-46,1972$

5）岩川幹夫：同上（II），治山17(3)，68-74，1972

6）勝井義雄 - 篠沢達也 - 知本康男 - 山田裕丈：北海道駒ヶ 岳の歴史時代の火砕流，火山噴火に伴う乾燥粉体流（火 硒流等）の特質と災害, 自然災害科学特別計画研究研究 成果，91-113，1986

7）松井善喜：駒岳爆発後11年間に於ける植生遷移，日林大 会号，47-57，1940

8）岡村俊邦：活火山地域における森林の成立過程に関する 砂防学的研究，地下資源調查所報告57，29-69，1985

9）岡村俊邦・柳井清治：噴火荒廃地における森林の成立過 程に関する砂防学的研究，新砂防40 (1)，5-13，1987

10）新村義昭・伊藤重右卫門・成田俊司・清水 一：山腹植 生工施工地への木本の侵入一渡島駒ヶ岳火山性荒廃地に 抢ける調查例一，日林北支講30，255-258，1981

11）鈴木建夫・勝井義雄・鎌田耕太郎：北海道駒ケ岳1929年 火砕流の堆積地形と堆積物の粒度分布, 火山噴火に伴う 乾燥粉体流（火砕流等）の特質と災害，自然災害科学特 別計画研究研究成果, 61-90, 1986

12）舘脇 操・柴草良悦・松下彰夫 -小島 覚: 渡島駒力゙岳 の植生, 日本森林植生研究会, pp. 82, 1966

13）津村昌一：駒ケ岳爆発による森林の被害及復興に就い て，北海道林業会報 27，753-769，1929

14）柳井清治：火山山麓における森林形成に関する実験的研 究, 北大農修論, pp. 118, 1981

15）吉井義次: 駒ケ岳爆発後の植物群落, 生態学研究 8(2〜3), 170-220, 1942

16）横山勝三：大規模火砕流堆積物の地形一その特性と問題 点一, 地形6 (2), 131-152, 1985

17) Yoshioka, K : Development and recovery of vegetation since the 1929 eruption of Mt. Komagatake, Hokkaido., Ecological Review 16(4), 271-292, 1966

(1993.10.28受理)

\section{Summary}

The natural vegetation process and the effect of afforestation work were studied on the pumice plain of Komagatake volcano, southern Hokkaido, Japan. The barren land, newly formed after a huge eruption in 1929, was mainly revegetated naturally by willows (Salix reinii and Salix integra), birches (Betula platyphylla), poplars (Populus sieboldii and Populus maximowiczii), and larch (Larix leptolepis). All the trees had extremely low growth rates attaining less than $3 \mathrm{~m}$ in height over 60 years; low water and nutrient availability probably limited growth. Tree ring analysis demonstrated that willow, poplar and birch have steadily invaded over the first 40 years, but that the non-native larch has remarkably increased within the past ten years. The forests have been changing from early successional deciduous trees to larch. The tree plantation work to promote earlier forest establishment was also carried out for the past 30 years. Four species were planted: larch, alder, pine and birch. The planted larch had the highest growth rate, followed by alder and pine. These planted trees reached $5 \mathrm{~m}$ to $8 \mathrm{~m}$ in height with the exception of birch. Soil condition on the understory of the plantations were remarkably improved compared to natural sites with a well-developed A-horizon and high nitrogen content. Plantations are successful for rapidly establishing forest and accelerating succession process on land devastated by volcanic activity. 